\title{
電離層におけるロケット排出物の拡散と電子減少*1
}

\section{Electron Depletion with Diffusion of Rocket Effluents in the Ionosphere}

\author{
石川芳 男*2 - 井上正 史*3 \\ Yoshio IsHIKawa, Masashi INOUE \\ 小宅 康 博*4 - 山 極 芳 樹*5 \\ Yasuhiro OYAKE, Yoshiki YamagIWA \\ 栗 木 恭 一*6 \\ and Kyoichi KURIKI
}

Key Words : Environment, Ionospheric Hole, Rocket Effluent

\begin{abstract}
In coming new space age, we will have frequent trips between the ground and mission orbits by large rockets to realize the large projects such as space stations and solar power satellite systems. In such cases a great deal of rocket effluents should be released in the atomosphere. But, its effects on our environment is still unknown, and therefore various studies on these problems are expected. About such environmental problems, some studies were performed which motivated by so called "ionospheric hole" observed when Skylab-I was launched, May 14, 1973. It was certified by later scientific studies that the phenomenon was caused by the chemical reaction between rocket effluents and ionized particles in the ionosphere, by which the electron density of the ionosphere suddenly decreased to about a half values of that in its normal state in the range of about $1,000 \mathrm{~km}$ in radius centering about rocket trajectory and it took about 4 hours to recover. In this study, the results of these fundamental studies are applied to the engineering problem, that is, the numerical simulation of the change in electron density in the ionosphere is carried out in consideration of the diffusion of rocket effluents released along arbitrary trajectory in upper atomosphere and their chemical reactions with the ionospheric constituents.
\end{abstract}

\footnotetext{
*1 平成 3 年 10 月 31 日, 第 35 回宇宙科学技術連合諈演会に て潇演. 平成 4 年 5 月 23 日原稿受理

*2 日本大学理工学部航空宇宙工学科

*3 (株) トキメック

*4 日本大学大学院

*5 静岡大学工業短期大学部機械工学科

*0 宇宙科学研究所
}

壾 号

$D_{\mathrm{a}}$ : 電子の拡散係数, $D_{\mathrm{b}}$ : 磁場に垂直な方向の電 子の拡散係数 (ボーム拡散係数)， $D_{i}$ : 気体 $i$ の拡散 係数, $D_{i j}$ : 気体 $i$ と気体 $j$ との相互拡散係数, $H$ : 酸素原子のスケールハイト， $H_{i}:$ 気体 $i$ のスケール 八イト， $I$ : 磁気伏角, $K$ : 電離層内に存在するガス の種類数。 $\vec{k}:$ 高度方向の単位べクトル, $L_{i}:$ 気体 $i$ の減少項, $L_{\mathrm{e} 1}$ : 電子減少率, $L_{\mathrm{e} 2}$ : 排出物による電子 減少率, $M$ : 電離層内を拡散するガスの種類数, $n[-]:$ : の密度 (例, $n\left[\mathrm{~N}_{2}\right]$ : 窒素の密度)， $n_{\mathrm{e}}$ : 電 子密度, $n_{i}:$ 気体 $i$ の密度, $n_{0}:$ 通常状態の電子密 度, $P_{i}$ : 気体 $i$ 生成項, $Q$ : 電子生成率, $Q_{0}$ : 最大 電離率, $R_{1} \sim R_{9}$ : それぞれの反応速度係数， $S_{i}$ : 気 体 $i$ の排出項, $T$ : 中性大気温度， $\vec{w}$ : 中性風速度, $\vec{w}_{i}$ : 気体 $i$ の应散速度， $x$ : 水平距離（南北方向）, $y$ : 水平距離 (東西方向) $, z:$ 高度， $z_{0} ： Q_{0}$ が現れる 高度， $\alpha_{i}$ : 気体 $i$ の熱拡散因子， $x$ : 太陽天頂角

\section{1.はじめに}

近い将来に予想される本格的な宇宙時代において は，現在とは比較にならぬほど頻繁なロケットの打ち 上げが必要とされるが，そうなれば地球大気中には大 量のロケット排出物が放出されることになる。しか し、これが地球環境にいかなる影響を及ほすすかはに んど未知であると言ってよく，したがって、ここに多 くの研究課題が残されている.

現在知られているこの種の現象の一つに，いわゆる 「電離層の穴」と呼ばれるものがある。これは 1973 年 5 月 14 日の Skylab-I の打ち上げの際に初めて観測 されたもので，このとき電離層内のロケット軌道に沿 
つて電子が大幅に減少し，その影響は半径 $1,000 \mathrm{~km}$ にまで及び、また回復までには 4 時間を要したとされ ている. その後の研究 ${ }^{1-3)}$ の結果, ロケット排出物と 電離層内の荷電粒子との間の化学反応が,こうした現 象をもたらすことが知られるようになった。

本報告は，これらの基礎的な研究の成果を，工学的 な問題へ応用することを目的とする。すなわち，任意 のロケット軌道に沿って放出されたロケット排出物 (ここでは水および水素分子)の電離層内での拡散とそ れに伴う化学反応を考慮して，そこでの電子密度の変 動の数值シミュレーションを行った。

\section{2. 電離層モデル}

電離層の主成分は，酸素原子イオンと電子から成る プラズマである．それに加えて少数の中性分子が数種 類存在している。これらの粒子は，電離層内で安定に その状態を保っているのではなく，絶えず太陽放射な どのエネルギーを吸収して電離状態を増進させ，その 一方，電離した分子や原子は中性分子と衝突して解離 再結合反応を引き起こす，つまり，ある電子密度にお いて，両者が釣り合うことによって電離層が形成され ている.

2.1 太陽光線による電離 電離盧の電離状態を記 述するためのモデルには，チャップマン分布4,6)を用 いた。このモデルは，大気を等温の平衡水平大気と仮 定し, 高度と太陽天頂角 $x$ を変数として電子生成率 $Q$ を表したものである。すなわち

$$
Q=Q_{0} \exp \left[1-\frac{z-z_{0}}{H}-\sec (x) \exp \left\{-\frac{z-z_{0}}{H}\right\}\right]
$$

ここでは，電離層の電子生成率 $Q$ は，太陽による 電離のみをもって表すものとする。

2.2 電離層内の電子減少反応 電離層内の電離状 態を減ずる要因として，次のような反応を考えること ができる，すなわち，イオンと原子の衝突によるイオ ン一原子交換反応

$$
\begin{aligned}
& \mathrm{O}^{+}+\mathrm{N}_{2} \stackrel{R_{1}}{\longrightarrow} \mathrm{NO}^{+}+\mathrm{N} \\
& \quad R_{1}=1.2 \times 10^{-12}(T / 300)^{-1}\left[\mathrm{~cm}^{3} / \mathrm{s}\right] \\
& \mathrm{O}^{+}+\mathrm{O}_{2} \stackrel{R_{2}}{\longrightarrow} \mathrm{O}_{2}^{+}+\mathrm{O} \\
& \quad R_{2}=2.0 \times 10^{-11}(T / 300)^{-0.4}\left[\mathrm{~cm}^{3} / \mathrm{s}\right]
\end{aligned}
$$

と，その生成化合物による解離再結合反応

$$
\begin{aligned}
& \mathrm{NO}^{+}+\mathrm{e}^{-\stackrel{R_{3}}{\longrightarrow}} \mathrm{N}^{*}+\mathrm{O}^{*} \\
& \mathrm{O}_{2}^{+}+\mathrm{e}^{-\stackrel{R_{4}}{\longrightarrow}} \mathrm{O}^{*}+\mathrm{O}^{*}
\end{aligned}
$$

である．前者の反応速度が後者のそれよりも遅いの で，電子の減少に対しては，前者が律速段階反応とな

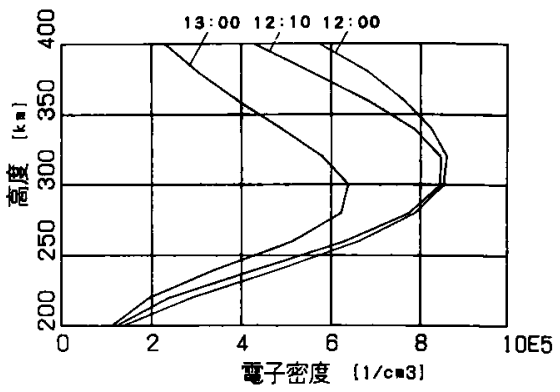

第1図 通常反応による電子密度分布

る.電子減少率 $L_{\mathrm{el}}$ は，電子の密度と酸素原子イオン の密度が電離層内で同じであると仮定すると, 律速段 階反応の反応速度と中性分子密度および電離層の電子 密度との積で表される。すなわち

$$
L_{\mathrm{e} 1}=\left(R_{1} \cdot n\left[\mathrm{~N}_{2}\right]+R_{2} \cdot n\left[\mathrm{O}_{2}\right]\right) n\left[\mathrm{e}^{-}\right]
$$

電子減少に関する反応はこれだけではないが，ここ

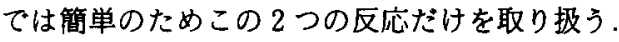

これらの反応を電離層内の「通常反応」と呼ぶこと にする. 通常反応は, 後述の電子の拡散方程式に化学 反応の項として組み込まれる．その㹡散方程式を用い て、電離層の通常電子分布を計算することができ，高 度に対する 1 次元分布を得る(第 1 図). 時間変動は太 陽天頂角の変化に伴うものである. 電子生成率 $Q$ は 米沢電離層モデル ${ }^{4,6)}$ の値を使用し, 電子減少率 $L_{\mathrm{e} 1}$ を計算するのに必要な中性粒子密度は CIRA 1972" の 外圈温度 1000 [K] モデルを用いた。 また，場所とし ては鹿児島県種子島沖 (北緯 30 度，東経 135 度) を例 にとった

\section{3. 排出物の拡散と電離層の穴}

3.1 排出物による電子減少反応 ロケット排出物 が引き起こす電子減少過程は，排出物の分子と背景分 子によるイオン一原子交換反応

$$
\begin{aligned}
& \mathrm{O}^{+}+\mathrm{H}_{2} \stackrel{R_{5}}{\longrightarrow} \mathrm{OH}^{+}+\mathrm{H} \\
& R_{5}=2.0 \times 10^{-9}\left[\mathrm{~cm}^{3} / \mathrm{s}\right] \\
& \mathrm{O}^{+}+\mathrm{H}_{2} \mathrm{O} \stackrel{R_{6}}{\longrightarrow} \mathrm{H}_{2} \mathrm{O}^{+}+\mathrm{O} \\
& \quad R_{6}=2.3 \times 10^{-9}\left[\mathrm{~cm}^{3} / \mathrm{s}\right]
\end{aligned}
$$

および，その生成化合物と電子による解離再結合反応

$$
\begin{aligned}
& \mathrm{OH}^{+}+\mathrm{e}^{-\stackrel{R_{7}}{\longrightarrow}} \mathrm{O}^{*}+\mathrm{H} \\
& \mathrm{H}_{2} \mathrm{O}^{+}+\mathrm{e}^{-\stackrel{R_{\mathrm{g}}}{\longrightarrow}} \mathrm{H}+\mathrm{OH} \\
& \mathrm{H}_{2} \mathrm{O}^{+}+\mathrm{e}^{-\stackrel{R_{9}}{\longrightarrow}} \mathrm{H}_{2}+\mathrm{O}^{*}
\end{aligned}
$$

を通じて行われる。ただし，液酸・液水エンジンの理 想的な燃焼を仮定して，分子状の水と水素のみを排出 物とした。また，高高度てはロケットの進行速度と～ 
スル出口での噴気速度はほほ等しいものとして噴気速 度の影響は無視した。

排出物による電子減少率 $L_{\mathrm{e} 2}$ は，（7），（8）を律速 段階反応として，

$$
L_{\mathrm{e} 2}=\left\{R_{5} \cdot n\left[\mathrm{H}_{2}\right]+R_{6} \cdot n\left[\mathrm{H}_{2} \mathrm{O}\right]\right\} n\left[\mathrm{e}^{-}\right]
$$

と表される。

前述の通常反応における電子減少率 $L_{\mathrm{el}}$ に比べて， 排出物による電子減少率 $L_{\mathrm{e} 2}$ がはるかに大きいために 電子減少率が高まり，電離層内の電子の生成と減少の バランスを崩す。これが、電子密度の著しい低下を引 き起こす。

3.2 排出物の拡散方程式 $K$ 種類のガスからな る大気中を拡散する中性ガスを考える．拡散する $i$ 種 のガスの搪散速度 $w_{i}$ は，次式で表される5)。すなわ ち

$$
\overrightarrow{w_{i}}=\vec{w}-D_{i}\left[\frac{1}{n_{i}} \nabla n_{i}+\frac{\vec{k}}{H_{i}}+\frac{1+\alpha_{i}}{T} \nabla T\right]
$$

ここで，拡散係数 $D_{i}$ は，相互拡散係数 $D_{i j}$ を用いて

$$
\frac{1}{D_{i}}=\sum_{j=1}^{K} \frac{1}{D_{i j}}
$$

のように表される．i種のガスについての連続の式は

$$
\frac{\partial n_{i}}{\partial t}+\nabla\left(n_{i} \cdot \overrightarrow{w_{i}}\right)=S_{i}+P_{i}-L_{i}
$$

で表される。

（15）に(13)を代入し，中性風，拡散係数および大気 温度は高度のみの関数とし，また熱㹡散因子の項を無 視する ${ }^{8.9)}$ と。

$$
\begin{aligned}
\frac{\partial n_{i}}{\partial t}= & -\left\{w_{x} \frac{\partial n_{i}}{\partial x}+w_{y} \frac{\partial n_{i}}{\partial y}+\frac{\partial}{\partial z}\left(n_{i} w_{z}\right)\right\} \\
& +\frac{\partial D_{i}}{\partial z}\left\{\frac{\partial n_{i}}{\partial z}+\frac{n_{i}}{H_{i}}+n_{i} \frac{\partial}{\partial z}(\ln T)\right\} \\
& +D_{i}\left\{\frac{\partial^{2} n_{i}}{\partial x^{2}}+\frac{\partial^{2} n_{i}}{\partial y^{2}}+\frac{\partial^{2} n_{i}}{\partial z^{2}}\right. \\
& +\frac{1}{H_{i}} \frac{\partial n_{i}}{\partial z}+n_{i} \frac{\partial}{\partial z}\left(\frac{1}{H_{i}}\right) \\
& \left.+\frac{\partial n_{i}}{\partial z} \frac{\partial}{\partial z}(\ln T)+n_{i} \frac{\partial^{2}}{\partial z^{2}}(\ln T)\right\} \\
& +S_{i}+P_{i}-L_{i}
\end{aligned}
$$

となる。ここで，Li $L_{i}$ は化学反応項であり，電子減少 反応に伴う排出物の減少を表している．また，中性風 を無視し， $n_{i}$ についてまとめると

$$
\begin{aligned}
\frac{\partial n_{i}}{\partial t}= & D_{i} \frac{\partial^{2} n_{i}}{\partial x^{2}}+D_{i} \frac{\partial^{2} n_{i}}{\partial y^{2}}+D_{i} \frac{\partial^{2} n_{i}}{\partial z^{2}} \\
& +\frac{\partial n_{i}}{\partial z}\left\{\frac{D_{i}}{H_{i}}+D_{i} \frac{\partial}{\partial z}(\ln T)+\frac{\partial D_{i}}{\partial z}\right\} \\
& +n_{i}\left\{\frac{\partial D_{i}}{\partial z} \frac{1}{H_{i}}+\frac{\partial D_{i}}{\partial z} \frac{\partial}{\partial z}(\ln T)\right. \\
& \left.+D_{i} \frac{\partial}{\partial z}\left(\frac{1}{H_{i}}\right)+D_{i} \frac{\partial^{2}}{\partial z^{2}}(\ln T)\right\} \\
& +S_{i}+P_{i}-L_{i}
\end{aligned}
$$

となる。

3.3 電子の拡散方程式 電子の拡散には地球磁場 の影響を考慮する必要がある，いま，扱う高度範囲で は大気温度が一定であるとすると

$$
\begin{aligned}
\frac{\partial n_{\mathrm{e}}}{\partial t}= & Q-L_{\mathrm{e} 1}-L_{\mathrm{e} 2} \\
& -\left\{\frac{\partial}{\partial x}\left(n_{\mathrm{e}} \cdot w_{\mathrm{e} x}\right)+\frac{\partial}{\partial y}\left(n_{\mathrm{e}} \cdot w_{\mathrm{e} y}\right)\right. \\
& \left.+\frac{\partial}{\partial z}\left(n_{\mathrm{e}} \cdot w_{\mathrm{e} z}\right)\right\}
\end{aligned}
$$

ここで，Q， $L_{\mathrm{e} 1}$ は通常反応の化学反応項であり， $L_{\mathrm{e} 2}$ は排出物による電子減少反応項である。また，電子の 拡散速度 $w_{\mathrm{e}}$ は

$$
\left.\begin{array}{rl}
w_{\mathrm{e} x}= & -\left(D_{\mathrm{a}}-D_{\mathrm{b}}\right) \sin I \cos I\left(\frac{1}{n_{\mathrm{e}}} \frac{\partial n_{\mathrm{e}}}{\partial z}+\frac{1}{2 H}\right) \\
& -\left(D_{\mathrm{a}} \cos ^{2} I+D_{\mathrm{b}} \sin ^{2} I\right)\left(\frac{1}{n_{\mathrm{e}}} \frac{\partial n_{\mathrm{e}}}{\partial x}\right) \\
w_{\mathrm{e} y}= & -D_{\mathrm{b}}\left(\frac{1}{n_{\mathrm{e}}} \frac{\partial n_{\mathrm{e}}}{\partial y}\right) \\
w_{\mathrm{e} z}= & -\left(D_{\mathrm{a}} \sin ^{2} I+D_{\mathrm{b}} \cos ^{2} I\right)\left(\frac{1}{n_{\mathrm{e}}} \frac{\partial n_{\mathrm{e}}}{\partial z}+\frac{1}{2 H}\right) \\
& -\left(D_{\mathrm{a}}-D_{\mathrm{b}}\right) \sin I \cos I\left(\frac{1}{n_{\mathrm{e}}} \frac{\partial n_{\mathrm{e}}}{\partial x}\right)
\end{array}\right\}
$$

と表される。Iは磁気伏角である。

反応の結果减少する分子と電子の数は一致するか ら，(17)と（18）の電子隇少率の関係は，次のように表 せる.すなわち

$$
L_{\mathrm{e} 2}=\sum_{i=1}^{M} L_{i}
$$

この電子の拡散方程式と, 取り扱う排出物の種類数 だけの㹡散方程式を連立して解くことにより，電離層 内での電子消滅を計算することができる。

\section{4. 計 算 条 件}

まず、計算を行うに当って設定した条件および仮定 について述べる。

ロケット排出物の静止大気中での拡散を想定し，計 算領域として高度方向に $200 \mathrm{~km}$ 加ら $400 \mathrm{~km}$ ，水平 方向に $800 \mathrm{~km} \times 200 \mathrm{~km}$ の 3 次元空間をとった（第 2 図)。数值計算には差分法を用い，空間ステップは 20 $\mathrm{km}$ とした。

電子の拡散係数 $D_{\mathrm{a}}$ は米沢電離層モデル4.6) の值を 使用し，拡散係数 $D_{i}$ とスケールハイト $H_{i}$ を計算す るのに必要な中性粒子密度および大気温度は CIRA 19727 の外圈温度 1000 [K] モデルを使用した。

地理的位置は，太陽天頂角，磁気伏角を決定するの に必要であり，北緯 $30^{\circ}$ ，東経 $135^{\circ}$ （鹿児島県種子島 沖）の地点を例にとった。 

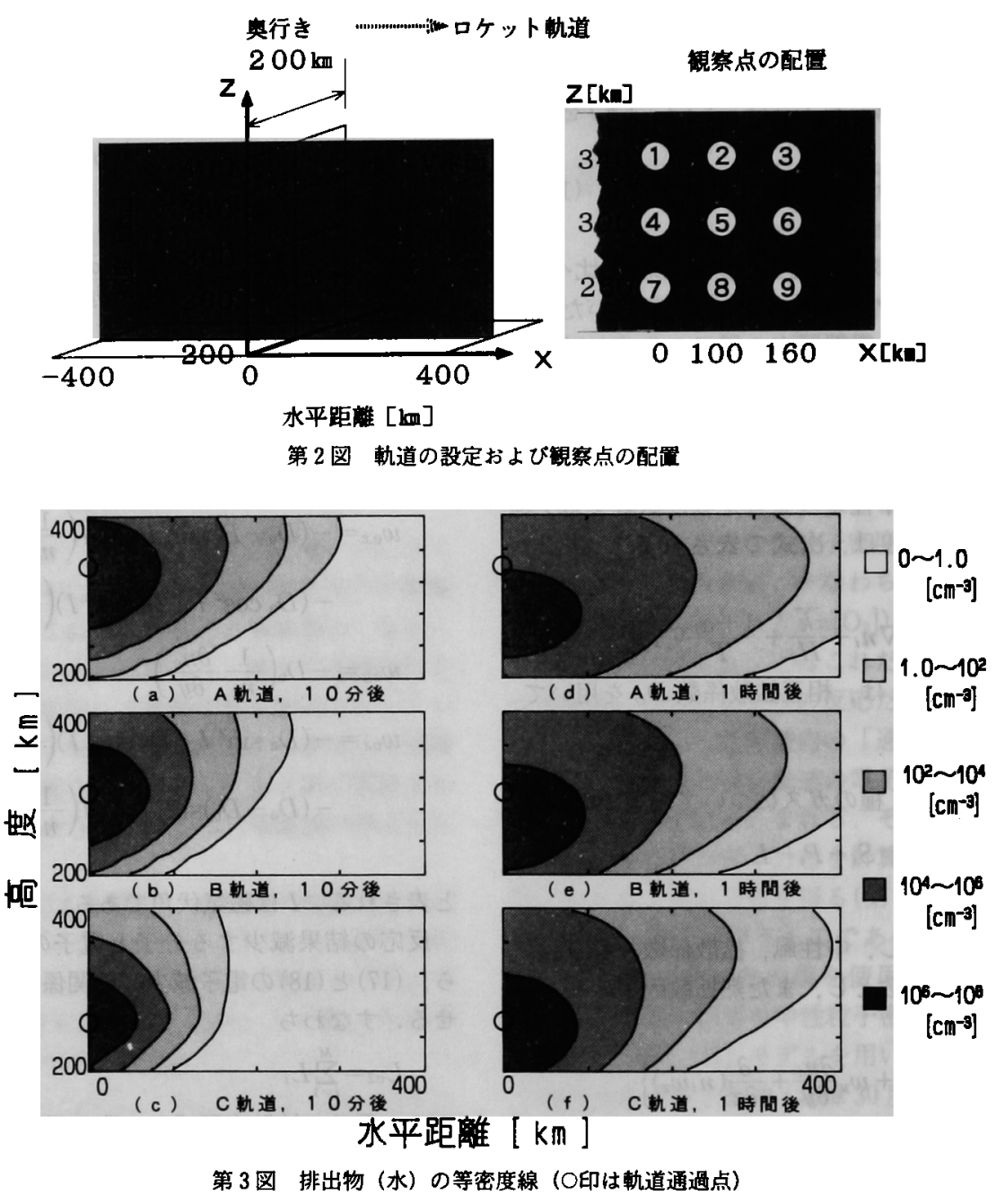

計算開始時間を昼夜平分時の正午と仮定して，太陽 放射による電離が盛んな時間帯の計算を行った。

ロケット排出物の放出は，ロケットの前述の計算領 域への進入から退出までの間，一定の割合で行われる ものとした．したがって，後述の計算結果において排 出直後と呼ぶのは，この計算領域への進入直後のこと である．排出物は水分子と水素分子とし，その存在比 は数密度で $3: 1$ とした ${ }^{2)}$.また，その量は軌道 $1 \mathrm{~km}$ あたり $1.2 \times 10^{26}$ 個であり，ロケットの速度は秒速 4 $\mathrm{km}$ の等速度とした。

\section{5. 計 算 結 果}

5.1 軌道高度の变化による影留 ロケットがガス を放出しつつ加速している状態て，完全な水平軌道を とることは考えにくいが、ここでは例として第 2 図の (A)，(B)，(C)のように高度の異なる水平軌道を仮
定し，軌道高度の違いが排出物の拡散と電子密度分布 にいかなる影響を及ぼすかを調べた，計算結果は，第 2 図中の V 平面内の水㧍よび電子の等密度線図とし て第 $3 ， 4$ 図に示される。ただし，V 平面は $Y$ 軸に 垂直であり，前述の計算領域を 2 等分する面でるる. また，静止大気中での拡散を仮定したので，水分子の 等密度線図（第 3 図）には, 軌道を含む半平面の結果 だけを示したが，地球磁場の影䇾のため搪散に異方性 を有する電子の等密度線図（第 4 図）には，軌道を中 心として左右 $200 \mathrm{~km}$ 筙囲の結果を示した。このと き，磁力線は V 平面内にあり，磁気伏角は 45 度てあ る. 次に V 平面内に(1)から(9)の観察点を設定し(第 2 図)，各点に抢ける排出物と電子密度の時間変化を第 5，6図として示す.

第 3 図は排出物の等密度線である，ただし，これは 数密度比 3 (水)：1 (水素)で放出された排出物のう 


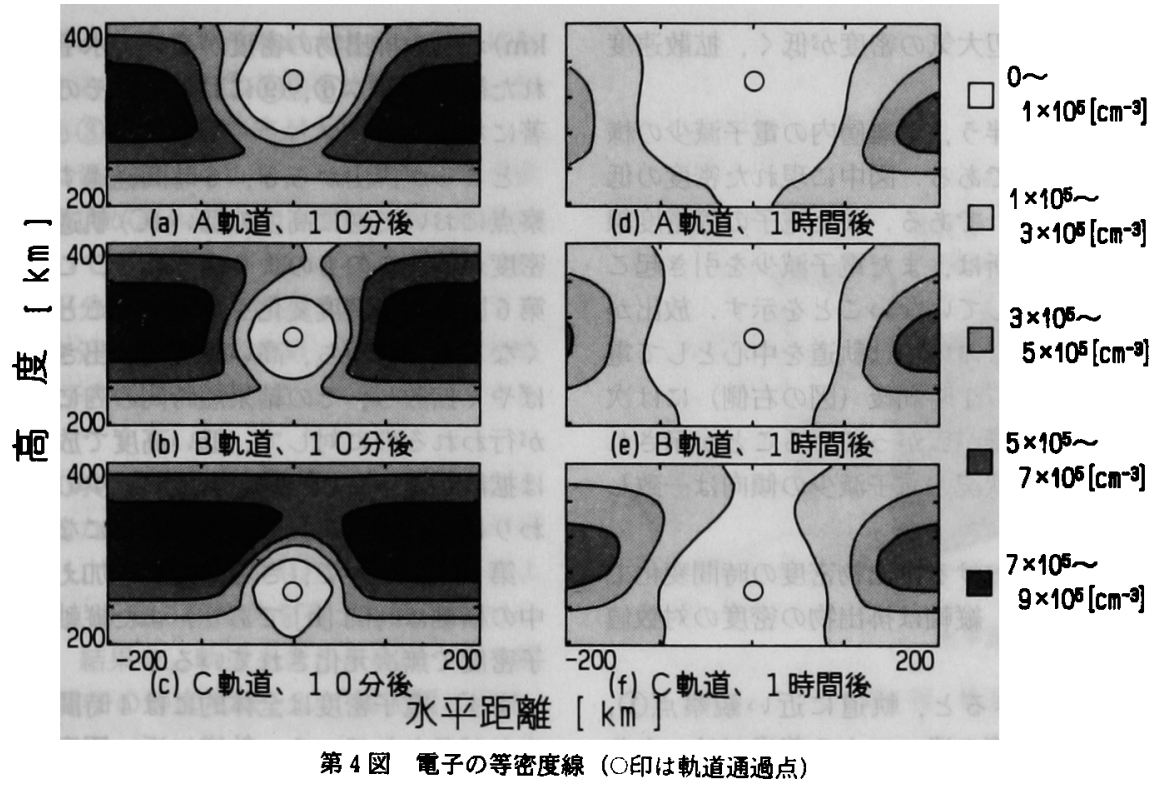

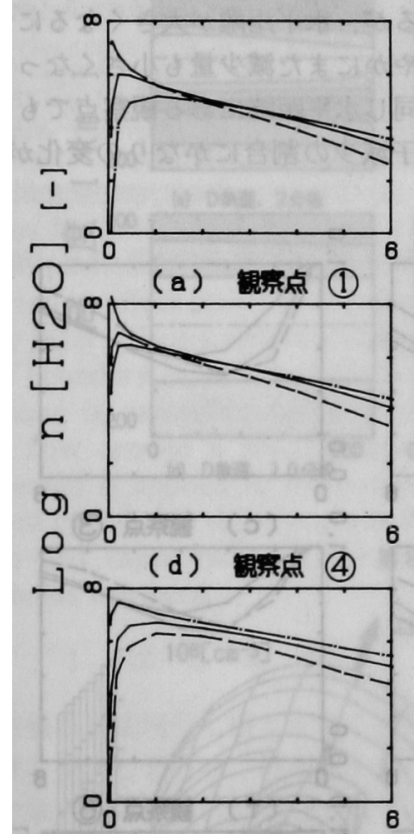

(g) 壪点 (7)

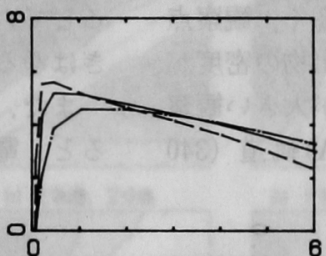

(b) 舅察点 (2)

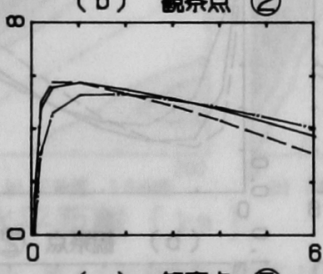

(e) 變点 (5)

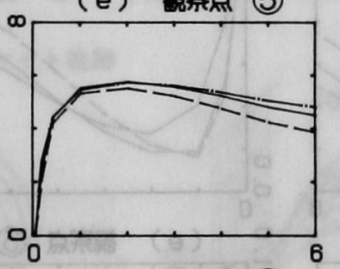

(h) (8)
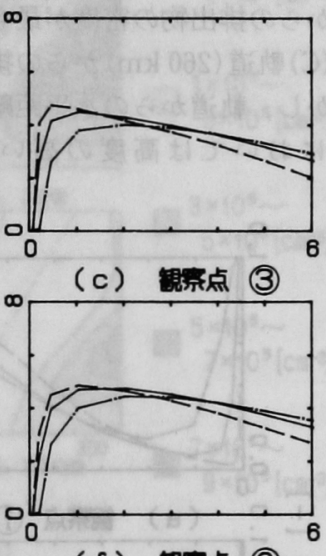

(f) 變点 (6)

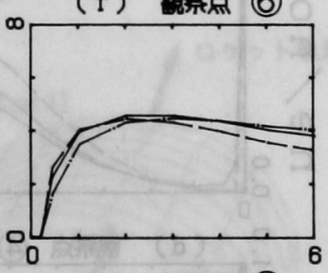

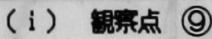

\section{時 間 [ $\mathrm{h}$ ]}

第 5 図 排出物密度の時間変化（点線仙 (A) 轨道、実線は (B) 軌道．鎖線は(C) 軌道)

ちの水分子についての例である. 水と水素では反応速 度俰数の大きさはあまり違わないが，水の方が量が多 いことと拆散速度が小さいことのため，結果的に電子 密度減少に大きく寄与することがわかっている．排出
物拡散速度は周辺大気密度と排出物密度の比によって 決まるため，周辺大気に比べて極めて高密度である排 出物は非常に速く拡散するが，第 3 図のどの場合にも 上空方向に特に大きく拡散する傾向が見られる。これ 
は高度が高い所ほど周辺大気の密度が低く，搪散速度 が高くなるためである。

上の排出物の拡散に伴う，電離層内の電子隇少の様 子を示したのが第 4 図である. 図中に現れた密度の低 い部分が「電離層の穴」である．また電子の等密度線 が水平層を成している所は，まだ電子減少を引き起こ すほどの排出物が到達していないことを示す．放出か ら 10 分後 (図の左側)においては軌道を中心として電 子減少が生じているが，1時間後（図の右側）には次 第に高い高度にその影筥が広がっていることが示され ており，排出物の拡散状況と電子隇少の傾向は一致し ている。

第 5 図は各観察点における排出物密度の時間変化て ある，横軸は時間 [h], 綎軸は排出物の密度の対数值 である。

排出直後についてみると、軌道に近い観察点(1), (4)、(7)に対して軌道高度の違いによる差違がはっきり と現れている.すなわち，観察点(1)においては $(\mathrm{A})$ 軌 道 $(340 \mathrm{~km})$ からの排出物の密度が最も高く、観察点 (7)においては (C) 軌道 $(260 \mathrm{~km})$ からの排出物の密度が 最も高い。しかし，軌道からの水平距離が大きい観察 点(2)，(5)、(8)に抢いては高度の高い(A)軌道（340 $\mathrm{km})$ からの排出物の密度が高い，水平距離がさらに離 れた観察点(3)，(6)，(9においてはその傾向はさらに顕 著になる。

ところが排出から 5 ， 6 時間経過すると，全ての観 察点において逆に高度の低い(C) 軌道からの排出物の 密度が他からのものより高くなる.このことは, 次の 第 6 図の電子密度変化を参照することにより理解し易 くなる.すなわち，高い高度で放出された排出物はす ばやく拡散し，その結果短時間の内に電子密度の回復 が行われるのに対して，低い高度で放出された排出物 は拡散が遅いため, 電子密度の減少の度合は小さいか わりにその影響が長時間続くことになる。

第 6 図について，さらに説明を加える，ただし，図 中の横軸は時間 [h] であり，また縦軸仗通常状態の電 子密度で無次元化されている。

まず，電子密度は全体的には 4 時間程度で回復する ことが示されている.軌道に近い観察点(1)，(4)，(7)で は，排出物の放出と同時にほほ壊隇的な電子隇少を起 こしているが，水平距離が大きくなるにつれ減少の㑯 きはわやかにまた減少量も小さくなってゆく，

また，同じ水平距離にある観察点でもその高度が異 ると, 電子減少の割合にかなりの変化が生じている.

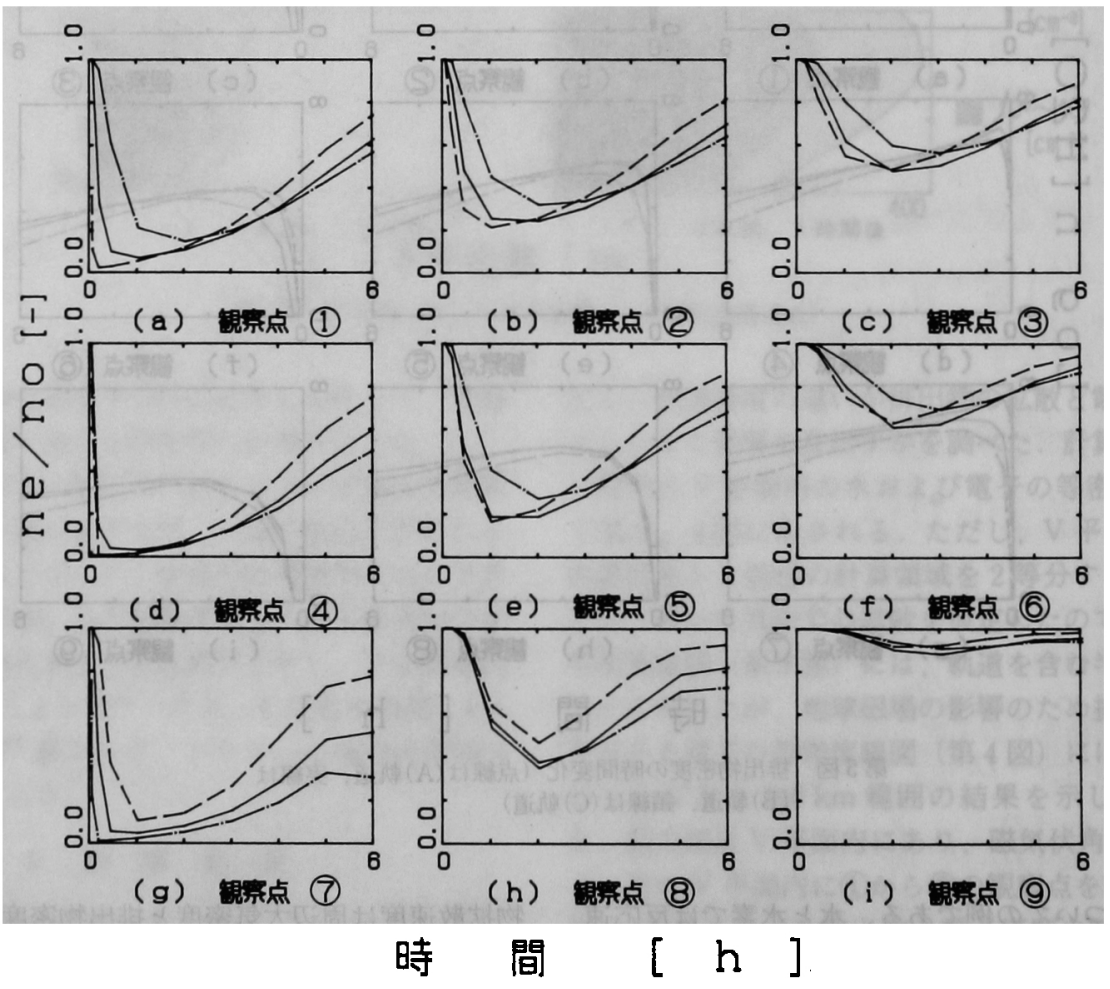

第 6 図電子密度の時間変化（点線は(A)軌道，実線は (B) 軌道，銧線は (C) 軌道) 
このことは，軌道からの水平距離が大きい観察点にお いて特に顕著である．観察点(3)と(9)を比較すると，20 パーセント以上も(3)隇少量の方が大きい。

さらに第 6 図には，放出加ら $5 ， 6$ 時間後に電子密 度の回復が鈍る傾向が現れている．特に，低い锶察点 (7)，(8)、(9においてその傾向が強い. 本計算例では， 放出時刻が昼夜平分時の正午と仮定されているので 6 時間後には日没を迎える，そのため，新たな電子生成 が抑制されて電子密度が回復しにくくなるためであ る.

5.2 軌道経路角の変化による影稫 本モデルは 3 次元モデルであるため，様々な軌道に对して計算が可 能である．例として，第 7 図の (D)，(E)，(F)のよ うに 0 度， 30 度，60度の経路角を有する軌道につい ての計算を示す．結果を，軌道を含む垂直面（第 7 図 のS 平面) 内の電子の等密度線として第 8 図に示す。

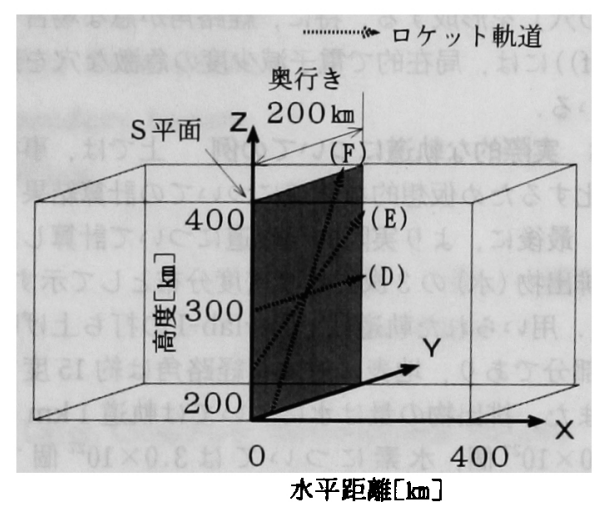

第 7 図 軌道の設定
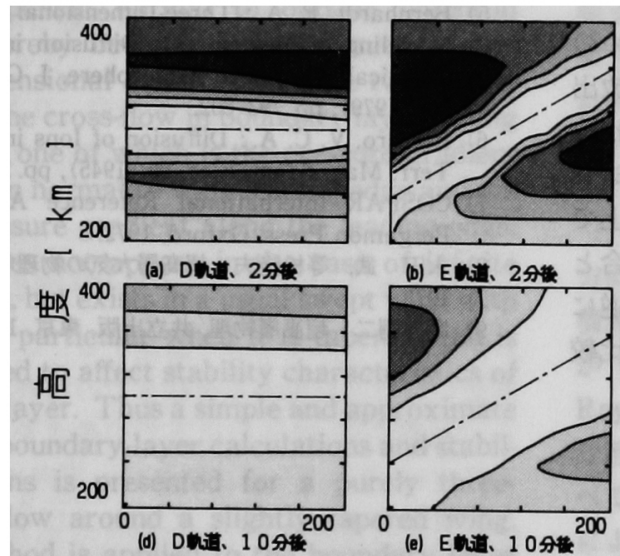
水平距離 $[\mathrm{km}$
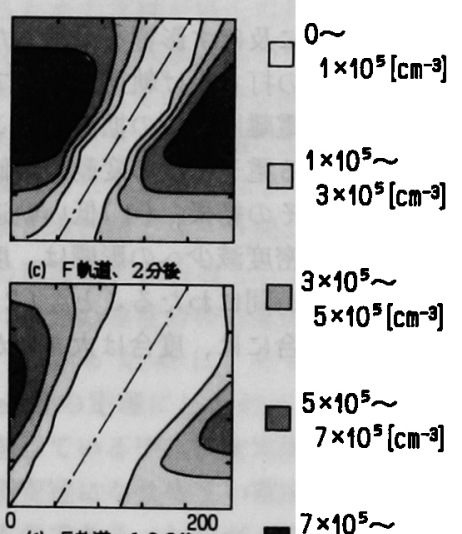

(f) F到、 10 分$$
\text { (f) }
$$

第 8 図電子の等密度線（銷線は軌道）

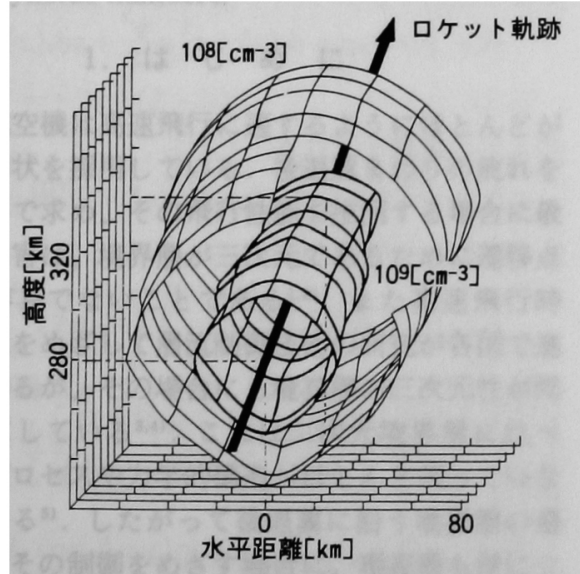

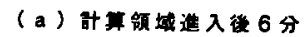

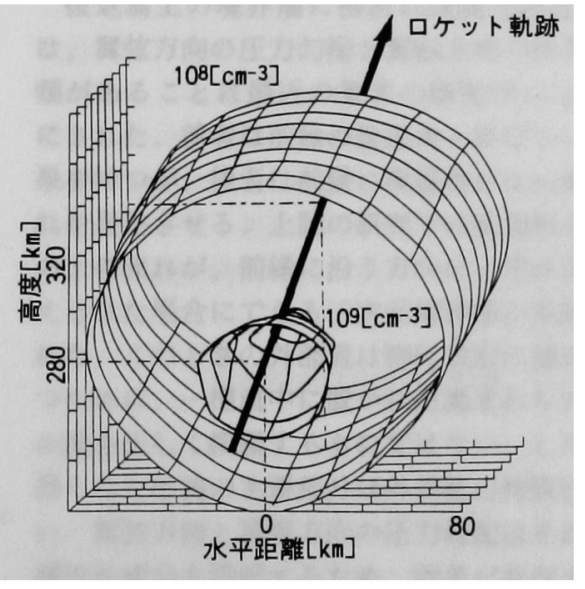

(b) 計算領域僬入後 16 分

第 9 図 排出物（水）の拡散 
2 分後（図の上側）には，軌道に浻って電子の減少が 現れている.10 分後（図の下側）になると，上下方向 に電子密度の减少域が広がり，大きくロを開いた「電 離層の穴」を形成する，特に，経路角が急な場合（第 8 図(f))には，局在的で電子減少度の急激な穴を形成 している。

5.3 実際的な軌道についての例 上では，事柄を 単純化するため仮想的な軌道についての計算結果を示 した，最後に，上り実際的な軌道について計算した例 を，排出物（水）の 3 次元的な密度分布として示す（第 9 図).用いられた軌道は，Skylab-I の打ち上げ軌道 の一部分であり，地表に対する経路角は約 15 度であ る。また，排出物の量は水については軌道 $1 \mathrm{~km}$ あた り $9.0 \times 10^{27}$ 個，水素については $3.0 \times 10^{27}$ 個であ る.

\section{6. まと め}

ロケット排出物が環境に及ぽす影響を見積るための 1 つの目安として，任意の打ち上げ軌道に沿って放出 されたロケット排出物の電離層内での拡散と、これに 伴う化学反応の結果生じる電子密度の変動の数值シミ ュレーションを行った．その結果，(1)低い軌道上で 放出された排出物の電子密度隇少への影響は, 度合と しては比較的小さいが長時間にわたること，(2)逆に 高い軌道で放出された場合には，度合は大きいが比較
的短時間の内に回復する傾向があることがわかった．

また，今回は電䧺層内における排出のみを考えた が，排出物の拡散が上方に向かって大きいことを考え ると，電離層より低い軌道上から放出された排出物も やがては電離層に影響を及ほすことが予想される。

\section{参考文献}

1) Mendillo, M., Hawkins, G. S. and Klobuchar, J. A. : A Sudden Vanishing of the Ionospheric F Region Due to the Launch of Skylab, J. Geophys. Res., 80, 16 (1975), pp. 2217-2228.

2) Zinn, J. and Sutherland, D. : Effects of Rocket Exhaust Products in the Thermosphere and Ionosphere, Space Soler Power Review, 1 (1980), pp. 109-132.

3) Zinn, J., Sutherland, D., Stone, S. N. and Ducan, L. M.: Ionospheric Effects of Rocket Exhaust Products HEAOC Skylab, J. Atoms. Terres. Phys., 44, 12 (1982), pp. 1143 -1171 .

4) Yonezawa, T.: Theory of Formation of the Ionosphere, Space Science Rev., 5 (1966), pp. 3-56.

5) Bernhardt, P. A. : Three-Dimensional Time-Dependent Modeling of Neutral Gas Diffusion in a Nonuniform, Chemically Reactive Atmosphere, J. Geophys. Res., 84, A3 (1979), pp. 793-802.

6) Ferraro, V. C. A. : Diffusion of Ions in the Ionosphere, Terr. Mag. Atom. Elec, 50 (1945), pp. 215-222.

7) COSPAR International Reference Atmosphere 1972 , Pergamon Press, Oxford, 1972.

8）永田 武, 等松隆夫: 超高層大気の物理学, 裳華房, 東京, 1973.

9）堀内㣚二：超高首物理, 共立出版, 東京, 1969. 